\title{
The class of instrumental ensembles, music history and solfeggio from virtuality
}

\section{La clase de conjuntos instrumentales, de historia de la música y solfeo desde la virtualidad}

MORALES-PÉREZ-TEJADA, Federico ${ }^{1} \dagger$, RODRÍGUEZ-JUAN, Arién ${ }^{1 *}$ and OSA-RICARDO, Arlena $^{2}$

${ }^{1}$ Universidad Autónoma de Zacatecas, México

${ }^{2}$ Escuela elemental de música Alejandro García Caturla, Cuba

ID $1^{\text {st }}$ Author: Federico Morales-Pérez-Tejada / ORC ID: 0000-0001-6613-5344

ID $1^{\text {st }}$ Coauthor: Arién Rodríguez-Juan / ORC ID: 0000-0003-4923-7431, CVU CONACYT ID: 566873

ID $2^{\text {nd }}$ Coauthor: Arlena, Osa-Ricardo / ORC ID: 0000-0002-2280-0127

DOI: $10.35429 / J E S C .2021 .14 .5 .14 .23$

Received: July 04, 2021; Accepted December 22, 2021

\begin{abstract}
Traditionally, music teaching has been developed in person, however, during the last years and after the appearance of the pandemic (COVID-19), it became necessary to adopt new models based on virtuality and thus continue with the teaching-learning process. This work aims to identify the most deficient aspects in the instructional design (ID) of the classes of Instrumental Ensembles and the theoretical ones of the music in conditions of virtuality in the Academic Unit of Arts of the Autonomous University of Zacatecas, Mexico. Essentially, a comparison was made in the development of the process and the academic results achieved by the students in each type of classes to determine which elements of the ID must be perfected for the continuity of the subjects from the virtuality.
\end{abstract}

\section{Class of Instrumental Ensembles, Theoretical classes of music}

\begin{abstract}
Resumen
Tradicionalmente la enseñanza de la música se ha desarrollado de forma presencial, sin embargo, durante los últimos años y tras la aparición de la pandemia (COVID-19), se hizo necesario adoptar nuevos modelos basados en la virtualidad y de esta forma continuar con el proceso de enseñanza-aprendizaje. Este trabajo tiene por objetivo identificar los aspectos más deficitarios en el diseño instruccional (DI) de las clases de Conjuntos Instrumentales y las teóricas de la música en condiciones de virtualidad en la Unidad Académica de Artes de la Universidad Autónoma de Zacatecas, México. En lo esencial, se realizó una comparación en el desarrollo del proceso y los resultados académicos alcanzado por los estudiantes en cada tipo de clases para determinar qué elementos del DI deben perfeccionarse para la continuidad de las asignaturas desde la virtualidad.
\end{abstract}

Clase de Conjuntos Instrumentales, Clases teóricas de música

Citation: MORALES-PÉREZ-TEJADA, Federico, RODRÍGUEZ-JUAN, Arién and OSA-RICARDO, Arlena. The class of instrumental ensembles, music history and solfeggio from virtuality. Journal Education Sciences. 2021. 5-14: 14-23

\footnotetext{
* Author Correspondence (e-mail: arienrguez@uaz.edu.mx)

$\dagger$ Researcher contributing as first author.
} 


\section{Introduction}

The study of music, like music itself and musical experiences, entail a series of benefits in the personal, professional and academic that influence the evolution of man, according to García-Gil and Cuervo (2020) cited in (2021)Gimeno, musical practices have supported the overcoming of shyness, selfesteem difficulties and situations of social exclusion.

... all the benefits that music generates, whether on a personal, academic or professional level, lead to a development of the individual, which favors his existence in the world around him, creating or sharing musical experiences, on a personal or interpersonal level, stimulating the emotional plane and consisting of a vocation or even a profession. (Gimeno, 2021, p. 18)

The teaching of music in a professional way must have as goals the effective assessment of music and the taste of the public, therefore, the student needs to acquire a complete preparation during his academic development that allows him to interpret any type of musical proposal with quality.

Traditionally, music has been taught in person, where the actors of the process, the teacher and the student, are in the classroom; however, due to the COVID-19 pandemic, new models that Educational Technology (TE) has introduced, specifically e-learning, have been required to continue with music teaching and face the new challenges that the new social normal brings.

As expected, the Academic Unit of Arts of the Autonomous University of Zacatecas (UAAUAZ) also relied on technology and virtuality, as fundamental tools, to continue with the training of its students and not stop their academic progress; this led teachers to devise new teaching strategies to meet this challenge, even though not everyone was trained to do so.

\section{Development}

The professional training of a musician requires the development of multiple knowledge and skills that combine to achieve an integral education, although the technique is fundamental for a correct instrumental execution (including the voice).
The practice is an indispensable pillar for this purpose, the correct interpretation of the extensive musical literature that exists, requires beyond the execution and the ability to decipher the score and understand its harmonic structures and contrapuntal, of a knowledge of the style in correspondence of the time and the composer framed in a historical context.

In this sense, in the academic and training process of the musician at the UAAUAZ, within the curricular map, the student needs to take the bachelor's level, but not before partially or totally studying in the institution the levels that precede the degree, or failing that, demonstrate, through an exam, that he has the knowledge and skills that correspond to the Basic and Upper Middle (MS) levels of music.

In the latter, subjects such as Solfeggio are included in the curriculum, which has been taught since the Basic level, and, in addition, those of History of Universal Music (HMU) and Instrumental Ensembles (IE) are integrated, the first two being considered as theoretical classes and the last as a practical class.

The Solfeggio class, despite being classified as a theoretical type, is a class that is developed in a theoretical-practical way and presents its bases in the knowledge and the practice of the teacher, which uses reproductive methods for instruction and that throughout history the lessons have been carried out in person. "Historically, the teaching of solfeggio is based on a 'teacher-learner' model that allows the student to obtain reliable feedback based on the experience and knowledge of the tutor." (Lasso, 2019, p. 4)

As already mentioned above, the Upper Middle level includes the History of Universal Music, in the same way, essential in the integral formation of the future professional musician, as stated in the description of the subject proposed by the National School of Music of the National Autonomous University of Mexico (ENMUNAM) (n.d.), represents a fundamental and indispensable part in the formation of a musician, which aims to provide the student with basic knowledge about the main stages of the development of Western musical culture, its currents, styles and most important musical forms, in this regard Morales (2012) tells: 
In general, the focus and raison to be of the History of Universal Music, within the Bachelor of Music programs is to study the music of man through its history, including information related to the most important facts, characters, dates and events of the various historical periods. (pages 321-322)

The scope of the subject can be very broad considering that in addition to contributing to the musical culture and stylistic knowledge of the performers, it can promote and strengthen other skills, such as musical creation, research, communication and pedagogy.

... depending on the way in which it is taught, it can provide tools for the enrichment and creation of new musical proposals and that the study of the history of music induces the student to reasoning, reflection and by equating their musical practice with the intellectual, in addition, through the subject the investigative and pedagogical spirit of the students can be fostered, develop their communicative skills and provide pedagogical tools for their future projection as a teacher of Music History. (Morales, 2012, p. 323)

For its part, the class of Instrumental Ensembles is of a practical type, the subject is considered a space where what is learned in the other classes is used, individually, and is oriented to group work.

The Instrumental Ensemble constitutes a space for training of the first order to experiment and apply, in addition to the skills acquired in the instrument class of the specialty, the knowledge acquired in all subjects. From this point of view, the set will also be able to travel the repertoire for different formations, of different eras or styles, which demonstrates once again that the Objectives of both subjects must be coordinated from a common perspective. (Instrumental Ensemble Programming, 2014, p. 1)

For his part, the pedagogue Cano (2018), establishes the importance of the subject of Instrumental Ensembles, fundamentally in the motivation, in addition, that he exposes that the work that is carried out in terms of tuning, filling, compliance with rules and presenting the execution of works, framed in different genres and styles, appropriate to their technical level.
Among other functions, facilitate the student's performance when it comes to being part of a future of orchestras and musical groups, as well as to couple with their fellow musicians and conductors; another of the benefits that the author points out focuses on the social development of the entity.

If we are able to achieve all this in these grassroots instrumental groups, we will be facilitating the work of future fellow musicians and conductors when these students access the titular bands of their associations, as well as enriching the musician in question both musically and socially. (Cano, 2018)

In the months of March-April 2020, the UAAUAZ assumes the necessary measures to face the pandemic and continue with the teaching-learning process virtually; therefore, the teachers of the aforementioned subjects saw the need to make changes in their ID to adopt new teaching models based on the use of TE tools.

\section{Educational Technology at the service of music education}

Technological progress has been notorious and has delved into most aspects of man's daily and social life, including education, which faces one of the most important changes of recent times, making timely use of the advantages offered by technology and thus favoring the academic development of students.

When conceptualizing About Educational Technology, we do not speak only of the inclusion of Information and Communication Technologies (ICT) within the class and as a support to instruction, "... the basic use of ICT by teachers is not a guarantee of competent professional practice"(Krumsvik, 2008; 2014, cited in Palau, Mogas, \& Ucar,2020, p.110), the authors agree with the pedagogues González and Flores (2020), who express that, a notion is made to a discipline that constitutes the progress of the media in combination with educational methods as tools for learning, which is mainly based on behaviorist theory. 
New teaching and learning modalities have been created thanks to the TE, among which it is worth highlighting the online model, which, therefore, imposes the mastery of certain digital skills by the teacher, which benefit their work in the new normal, among which we can mention the communicative, technological, research and pedagogical. It is precisely elearning that is the solution to the challenges posed by the health situation in the world.

Among the main difficulties identified worldwide in the professional teaching of music because of the pandemic, is virtualization, imposed by necessity overnight, without the implementation design that merited an educational transformation of this magnitude. "The massive virtualization of class teaching generated concern in society about a possible negative impact of "non-attendance" on the quality of education. Some careers seemed to be especially affected, such as those in the arts." (Piachonkina, 2020, p. 16). In addition, the author lists a series of aspects that must be taken into account so that the process of musical teaching is carried out with quality: it is necessary to discriminate the information that is going to be transmitted, in order not to saturate the apprentice with junk content; also, to establish well-stipulated class schedules, the terms and conditions of deliveries of welldefined tasks and that the system by which the evaluation is carried out is clear.

Despite the above, it is necessary to consider the adverse situations that may arise during the development of the course, "... we should not underestimate the problems of connectivity, the stress generated by the prolonged use of electronic devices, the overlap of the environments that traditionally used to be separated: the house and the educational institution." (Piachonkina, 2020, p. 19) The process of change to a virtual modality required a training proposal not only based on the knowledge of concepts and contents of the subject to be taught, but also of Educational Technology as a source of information transmission and manager of learning; with this premise, the realization of an Instructional Design focused on the e-learning model for the subjects of Solfeggio, History of Universal Music and Instrumental Ensembles is thought, which allows to systematically implement the activities that guarantee the appropriation of knowledge.
The ID is conceived as a way to guarantee an optimal level of teaching, when carrying out the analysis of the document, it is appreciated that authors such as González and Flores (2020) and De la Torre y Sosa (2018) refer to it as the planning prior to the instruction process, that is, the table work where the means and the form of use are planned and established, taking as its central axis the characteristics of the students; The above is presented under three fundamental premises: the recognition of the results of the teaching process, the introduction of the contents within it and the way in which the teaching-learning process is evaluated.

The model that was applied for the instructional design of the subjects already mentioned and that led to the adaptation of these to virtuality due to the health situation caused by COVID-19 was the ASSURE model (for its acronym in English: Analizer learners, State objectives, Select media and materials, Utilize media and materials, Require leaner participation and Evaluate and revise), which, De la Torre and Sosa (2018) explain, is considered a model based on a conductivist, eclectic, constructivist and cognitive approach, which gives teachers the power to subordinate the planning, development, assessment and modification of learning environments to the needs of the apprentices in their charge. This model is applied in six moments ranging from the analysis of the students to the evaluation of the implemented course and the elements that integrate them.

As a starting point in the implementation of the DI ASSURE, the analysis of the students (A) is carried out, for which three fundamental aspects were established: the characteristics of the students, the knowledge of entry to the course and the learning style that predominates in each of the students.

Taking into account the result of the analysis of the learners, we proceed to establish the objectives of the course, the didactic units to work, as well as the lessons (S); subsequently the means, materials and resources that are going to be used (S) are raised, it must be taken into consideration that sometimes the tools required for instruction can be found, however, other times it is necessary to make adaptations or the creation of such resources for their implementation $(\mathrm{U})$, this in order to promote the participation of students during the class $(\mathrm{R})$. 
Finally, the model proposes the evaluation of the course $(\mathrm{E})$; to have data as close to reality as possible, it is advisable to make the assessment considering: the academic development of the students during the course, the implementation of the tools, elements, means and materials, as well as the performance of the teacher. The assessment made allows the corresponding adjustments to be made for the improvement of the ID and its future implementation.

\section{Methodology}

The need to adopt a model that favored the continuity of the instruction process in the subjects of Solfeggio, History of Universal Music and Instrumental Ensembles of the Upper Middle level of the Bachelor of Music with emphasis on uaauaz instrument, determined the combination of methods for the search for theoretical-practical references that would enable the adequacy of the ID.

In this case, methods such as documentary analysis, survey and pedagogical observation were used; the characteristics of the platform and the selected model led to the use of tools and resources that allowed to visualize the development of the competences established in the programs of the subjects, as well as the creative activity of the students, taking as a starting point the instructions of the teachers. For the research there was a sample of 19 students of Instrumental Ensembles, 32 students of History of Universal Music and 13 of Solfeggio who study the subjects in semesters I, III and V of the Upper Middle level of the Bachelor of Music with emphasis on instrument.

\section{Discussion of results}

Despite the fact that more than a year has passed since the musical pedagogical process is carried out from virtuality, the work in the aforementioned subjects still presents adverse elements, which are sometimes alien to the will of the actors of the teaching-learning process such as: the unstable internet connection presented by students and teachers, health situations that directly affected one or the other, or failing that, family members, the socioeconomic situation of the students, among others, which caused moments of tension and negative reactions towards the study on the part of the students.
In the feedback surveys carried out at the end of the courses in the subjects of HMU, Solfeggio and IE, the apprentices expressed feeling greater progress, in terms of academics, in the subjects of a theoretical type in relation to the practical subject, where even, respecting the measures established by the state and institutional authorities, during the last three weeks it was required to make effective some classes in person, as a result it was possible to observe a notable difference in its evolution in the three face-to-face classes compared to what has been worked so far in the semester through virtuality.

The documentary analysis showed that this perception did not occur only in the institution, but that, in the Autonomous University of Aguascalientes (UAA), belonging to the same region as UAAUAZ, the same feeling was presented regarding the musical pedagogical process in virtuality. "The most effective subjects have been those that are not practical, since it is easy to leave the written instructions and do the work that is commissioned (CE-12). Due to their theoretical nature, it is easier to adapt them to this modality (EC-21)". (Carbajal-Vaca, 2021, p. 22)

As for the DI ASSURE model, it is perceived that its implementation had its differences caused by the type of class in which it was developed. In the first phase, (A) the analysis of the students, was focused on establishing the characteristics of the same and presented points in common in all the subjects, however, when establishing the predominant learning style in the students, it was observed that: by its nature of practical type, in the class of Instrumental Sets it was assumed, on the part of the teachers, that kinesthetic learning predominated within the different groups, meanwhile, in the classes of Solfeggio and History of Universal Music facilitated the application of the VARK questionnaire, which exposed the mastery of different learning styles, predominating literacy and auditory styles, within the class groups.

(S) The objectives were established according to the competencies marked in the different work programs and were always subordinated to the characteristics of the students, again, assuming that the ES class is practical the objectives focused on the work of interpretation, assembly, filling and tuning. 
In the development of the theoretical classes, the search for resources, materials and means to transmit knowledge (S) focused on the discrimination of information, the creation and modification of didactic and technological materials such as videos, audios, podcasts, documents in .pdf, digital presentations, materials for individual and collective work and the programming of courses in the educational platform (LMS-Moodle); for its part, in the class of Instrumental Ensembles during this stage was charged to the conformation of the musical groups in which the student would work depending on the instrument he studies and in the search for the music they were going to interpret, it is worth noting that phase 1 of the Instructional Design was taken into account.

In the next phase (U), the necessary resources, tools and materials were prepared; in the theoretical subjects, the courses were mounted on the LMS platform (for its acronym in English: Learning Management System) MOODLE, which supported the development of progress and activities during the semester and in the same way, served as a means of communication between teacher-student-group. On the other hand, at this stage little or no work was done in the ES classes, this because practically the only thing that was done was to establish the class schedules to work.

In the fifth moment of implementation of the ASSURE model, (R) once again the differences between the practical and theoretical classes are identified, the latter allowed the planning of both synchronous and asynchronous activities, thus facilitating self-taught learning.

Within the planning of the pedagogical activities designed to be applied in virtuality, it can be decisive to choose between the options of synchronous and asynchronous interaction, which are the ones that provide greater flexibility to the e-learning model, considering the affectations that occur after the drastic reduction suffered by the contact between the actors of the musical pedagogical process. "In this context, decisions made about synchronous or asynchronous interaction between teachers, students, and their families are of particular importance (Offir et al., 2008, cited in Palau, Mogas, \& Ucar, 2020, p. 110).
In the subject of History of Universal Music, synchronous activities focused on interaction through weekly videoconferences, allowing dialogue and contrast of information previously obtained individually by students, where the participation of the teacher promoted discussion, analysis and consolidation of knowledge, other ways to favor constant interaction between students during the semester, generally asynchronous, were forums and teamwork.

It should be noted that research is an essential part of this subject as a strategy to promote the acquisition and development of selftaught skills, so necessary in virtuality, which also contributes to one of the objectives established by UNESCO (2010)in pursuit of the development of education and which dictates "stimulate the exchange between research and practice in the field of art education" (p.6).

Likewise, Piachonkina (2020) states that: $" . .$. it is hoped that this type of internship can contribute to awakening in students' curiosity and, in the long run, the natural interest in research as part of musical work." (p. 19)

Meanwhile, in the Solfeggio class, asynchronous activities were programmed, such as the delivery of tasks for the realization of documents and podcasts by the students, databases where the trainees captured videos interpreting melodies and tunes according to the objective of the unit, collaborative work was promoted through the execution of canons.

And the use of activities such as the workshop; the feedback survey of the course exposed that the students were very motivated with the activities of musical creation, they felt wrapped up thanks to the constant communication both by the messaging of the educational platform and by the synchronous activities that were organized such as videoconferences, which were channeled mainly to the resolution of doubts and the exercise of some specific exercise to reaffirm the information that was provided to them. 
The work in the subject of Instrumental Ensembles was developed, mostly synchronously, through two weekly videoconferences in which each of the members of the different groups was reviewed, individually interpreting fragments of the assigned works, while the other companions listened or if possible played with them with their microphones off, share the pdf of the score on the screen and make annotations digitally, in addition to maintaining communication between the teacher and the members of the ensembles, the WhatsApp application was used; It is worth clarifying that asynchronous activities were scheduled where they were asked to make recordings and share them, by the same means used for communication, with their groupmates and with these to carry out the practice having a musical base on which to rely, however, due to different circumstances they could not always be brought to fruition.

The last step of the DI ASSURE model is the evaluation and review (E), this as it has already been established previously allows to perfect the course and improve those elements that are considered necessary, for its application in future semesters.

The first aspect in the evaluation is oriented to the academic performance of the students during the development of the semester. In the subject of Solfeggio, diagnoses were made gradually, the activities that had to be delivered weekly helped to assess the progression of each of the students, which allowed the teacher to see what were the skills that should be practiced and draw strategies for their work in videoconferences. At the end of the semester a knowledge and skills test were carried out that allowed a more general assessment of everything that had been learned during the course.

To establish the level of learning achieved in the subject of History of Universal Music, the quality and depth with which information was provided was considered and replicated in each of the forums aimed at sharing the researched knowledge, both individual and group tasks and works and oral and written participations in the videoconferences that also served as an attendance pass to them.
As for the academic performance of students in the subjects of Solfeggio and History of Universal Music, a significant advance was seen with respect to the diagnosis made at the beginning of the semester in the first phase of the DI, work must continue in terms of responsibility towards the fulfillment of the deadlines for delivery of activities, which affected some students in terms of the grade obtained in the semester.

The evaluation of the course and the performance of the teachers in the theoretical subjects by the students was carried out through a feedback survey carried out anonymously and at the end of the course, the results of the same show that:

The LMS-Moodle platform was very friendly, the exercises and asynchronous activities served to practice the knowledge acquired, one of the problems, which they constantly expressed, was the unstable connection to the internet and not being able to participate constantly in the videoconferences for work reasons, family matters, splices of schedules, mainly when the teachers of other subjects cited them at the same time as the theoretical music classes, or for health situations, however, they expressed that the teachers of the classes provided opportunities for the realization of activities, the strategies drawn up for these classes together with the option of being able to visualize the recordings of the video classes made were outstanding elements.

Also, the students expressed that, at all times, the communication, between studentteacher-group, was effective, which made them feel sheltered and cared for; the means of communication, such as forums, chats and group and individual messaging, where communication was synchronous and asynchronous, were judged as appropriate, in addition, it is observed that the appreciation of the students is favorable in that the communication was complemented by the synchronous activity of the videoconferences; finally, the way in which they shared information and discussed it was adequate and effective. 
As a final activity in the semester of the subject of Instrumental Ensembles, it was established the delivery of a video that previously had to upload to YouTube and share the link with the teacher; the video would include both the audio they recorded together, or that they edited recording separately, as well as information about the composer and the work. In addition, they were also asked to make a selfcriticism of the shared video in relation to 1 . Good aspects, 2. Bad aspects and 3. Difficulties.

In turn, the same feedback survey showed that in terms of the development of the semester there were diverse opinions, where it is denoted who had the opportunity to work some classes in person, it must be considered that there were groups that did not receive classes under this model and that the work was carried out completely through virtuality.

However, there is a general opinion, among the students, channeled to how slow this subject is worked in the e-learning modality, as a cause of this deficiencies are established such as: the gap between audio and video in synchronous activities (videoconferences), the little responsibility on the part of the students when delivering audios and videos to be able to carry out practices, the poor attitude to study, the unstable internet connections by which it was sometimes impossible to work with the teacher.

Opinion of student who did not have any face-to-face class in the semester:

As has happened in recent semesters the class had to be taken online which because this subject is worked in a group made it difficult to develop the work but using the editing tools and the guidance of the teacher could reach a result as close as possible to if we had played together live. As for the bad aspects I think it was mainly having to work the subject online since many times personally this does not allow me to understand how the work should sound in terms of what is related to the expression, but despite having those difficulties there were also good things such as the orientation of the teacher which was of great help to understand and have a clearer idea of how it should sound, plus it's an opportunity to get to know new music.
Already in general I think that taking into account the situation worked well and reached $a$ result which although it was not excellent was acceptable. We can only thank the teacher for his support and willingness so that we could have the best results, as well as my colleague who in the same way always showed willingness so that we could get a good product.

Opinion of student of instrumental ensembles who had two face-to-face classes at the end of the semester:

Good day, in the elaboration of this work we find several issues. mentioning good aspects are that I was happy to be able to live together again after so long, returning to the classrooms and playing together, with classmates and teachers, the work was different compared to online classes. Among the bad aspects are that I was stressed when studying, or at the time of recording, I was nervous when playing, but we still managed to get good recordings. In the difficulties it is found that sometimes we play well, but then because of the nerves we could not enter together, in time. and to finish regarding the development of the semester I think it was good, we did well during the classes, and I also appreciate the patience of the teacher, or that sometimes despite how we were, always at the end of the class encourages or motivates us to continue moving forward.

It is necessary to comment that the generalized opinion of the students, expressed through the surveys, as well as what could be observed, is distinguished that technology and its tools do not present the same use for theoretical classes as for practices in musical pedagogy, which is not an exclusive idea of the students and teachers of the UAAUAZ, but the documentary analysis revealed the same thought in several articles. In interviews conducted by Carbajal-Vaca (2021), learners express a similar feeling.

In addition to the general perception, the answers show that the technological resources available do not have the same functionality for all subjects... There are certain difficulties in carrying out a class as practical and ensemble as chamber music (CP-1). It is a bit difficult to work remotely, especially on the instrument and chamber music, since not all the technical aspects can be worked on (CP-5). 
My experience as a teacher in this situation has been difficult for me, the instrument class is face-to-face, therefore, too much information and time is lost when it is done through video-call, in addition tothe fact that the audio is not the same as live (CP-16). (p. 19).

\section{Conclusions}

The new normal, caused by the COVID-19 pandemic, leads to the adoption in education of the educational models introduced by the TE, which favor remote work in subjects such as Solfeggio, the History of Universal Music and Instrumental Ensembles, which were traditionally developed in person.

The characteristics of the adopted instructional design, ASSURE model, facilitated the work in theoretical subjects such as Solfeggio and the History of Universal Music, making possible the continuity of the teaching process and the active and creative participation of the students, this despite the difficulties that arose during the course.

On the other hand, the development of practical subjects, such as Instrumental Ensembles, were less benefited by the change to a virtual modality; the difference between the work is very noticeable, in terms of the development of the instructional design, when comparing the subjects of one type and another.

Those who subscribe have come to the conclusion that the differences, referred to above, are mainly due to the predisposition to carry out a practical subject in person and although the shortcomings that arise are recognized, on the part of the technology in terms of audio, details that do not become perceptible through technological devices and connection problems, creativity in the strategies that are drawn up by teachers can improve the teaching-learning process and increase motivation towards study.

\section{References}

Cano, V. (31 de octubre de 2018). La importancia de las asignaturas de conjunto instrumental y banda infantil en las Escuelas de Música. Obtenido de La Verdad: https://blogs.laverdad.es/febandasrmurcia/2018/ 10/31/la-importancia-de-las-asignaturas-deconjunto-instrumental-y-banda-infantil-en-lasescuelas-de-

musica/?ref=https\%3A\%2F\%2Fwww.google.c om $\% 2 \mathrm{~F}$

Carbajal-Vaca, I. S. (2021). Nuevas sonoridades en la educación musical: Voces universitarias ante la pandemia COVID-19. MAGOTZI Boletín Científico de Artes del IA, 9(17), 17-25. Obtenido de https://repository.uaeh.edu.mx/revistas/index.ph $\mathrm{p} / \mathrm{ia} / \mathrm{issue} /$ archive

De La Torre, V. R., \& Sosa, R. (Diciembre de 2018). La pertinencia del modelo de diseño instruccional ASSURE para la implementación de la educación a distancia. Revista Digital FILHA (en línea)(19). Obtenido de http://www.filha.com.mx/upload/publicaciones/ archivos/20181231203275_modelo_assure.pdf

ENMUNAM. (s.f.). Licenciatura en Música. Instrumentista. Programa de Asignatura. Programa, Escuela Nacional de Música, Universidad Nacional Autónoma de México. Obtenido de https://www.fam.unam.mx/div/cim/licenciatura/ mapas_web/pdf/inst_cuerd_alien/semestre_1/hi st_music_univ_1.pdf

Gimeno, P. (2021). El Impacto de la Música y la Educación Musical durante la Pandemia de la Covid-19. Trabajo Fin de Grado Magisterio en Educación Primaria, Universidad de Zaragoza, Facultad de Educación, Zaragoza. Obtenido de https://zaguan.unizar.es/record/106388/files/TA Z-TFG-2021-2617.pdf

González, N., \& Flores, G. M. (2020). Tecnología Educativa. En S. Cordero, \& V. Torres (Edits.), Tecnología Educativa. Propuestas para la implementación en el contexto escolar (págs. 11-32). Zacatecas, México: Texere. 
Lasso, D. R. (2019). Monitor tecnológico para el estudio del solfeo. Tesis, Universidad del Rosario. Escuela Colombiana de Ingeniería Julio Garavito., Bogotá.

Palau, R., Mogas, J., \& Ucar, M. J. (2020). ¿Cómo han gestionado los conservatorios de música españoles los procesos de enseñanzaaprendizaje durante el confinamiento del COVID-19? Revista Electrónica LEEMEJournal of Music in Education. Revista arbitrada sobre investigación y aplicaciones en Educación Musical(46), 108-124. doi:DOI: 10.7203/LEEME.46.18110

Piachonkina, Y. (2020). Música en línea: Estrategias y herramientas pedagógicas para la educación musical virtual. En Blanco \& Negro, 11(1), 14-22. Obtenido de https://revistas.pucp.edu.pe/index.php/enblanco ynegro/article/view/23188/22202

(2014). Programación de Conjunto Instrumental. Programa, Conservatorio Municipal Elemental de Música de Herrera. Obtenido de http://www.conservatorioherrera.com/wpcontent/uploads/2014/03/Programaci\%C3\%B3n -de-Conjunto-instrumental.pdf

Sosa, R. (2020). Software de apoyo para la dirección de proyectos de tecnología educativa. En Tecnología Educativa. Propuestas para la implementación en el contexto escolar (págs. 143-158). Zacatecas, México: Texere.

UNESCO. (2010). La Agenda de Seúl: Objetivos para el desarrollo de la educación artística. Segunda Conferencia Mundial sobre la Educación Artística, Seúl. Obtenido de http://www.unesco.org/new/fileadmin/MULTI MEDIA/HQ/CLT/CLT/pdf/Seoul_Agenda_ES. pdf 